\title{
Nutrient partitioning between reproductive and immune functions in animals
}

\author{
Jos G. M. Houdijk ${ }^{1 *}$, Neil S. Jessop ${ }^{2}$ and Ilias Kyriazakis ${ }^{1}$ \\ ${ }^{1}$ Animal Nutrition and Health Department, Animal Biology Division, Scottish Agricultural College, West Mains Road, \\ Edinburgh EH9 3JG, UK \\ ${ }^{2}$ Institute of Ecology and Resource Management, The University of Edinburgh, West Mains Road, \\ Edinburgh EH9 3JG, UK
}

\begin{abstract}
The physiological processes that underlie the reproductive cycle impose considerable metabolisable protein (MP) demands on a female, especially during the periparturient period. When MP supply falls short of MP demand (i.e. MP becomes scarce), certain, if not all, bodily functions are expected to be penalised. It has been proposed that partitioning of scarce MP is prioritised to reproductive rather than to immune functions. In other words, at times of MP scarcity, the penalty on expression of immunity would be expected to be greater than that on reproduction. This hypothesis forms a nutritional basis for the occurrence of periparturient breakdown of immunity to parasites (BIP), which can be observed in many host-parasite systems. In the present review we explore this nutritional basis, using periparturient sheep infected with the abomasal nematode Teladorsagia circumcincta as an example, and attempt to quantify its occurrence. Evidence supporting the nutritional basis of periparturient BIP is reviewed, covering experiments in which nutrient supply (from both exogenous and endogenous sources) and/or nutrient demand were manipulated. Quantitatively, MP requirements for expression of immunity to $T$. circumcincta were estimated to be about $1 \mathrm{~g} / \mathrm{kg}$ metabolic body weight (body weight ${ }^{0.75}$ ) per d, approximately $5 \%$ of the maximum MP requirements of periparturient sheep. The major component of this requirement was assumed to be for replenishing irreversible plasma protein losses into the gastrointestinal tract. Although confirmation of this estimate is required, such estimates may be used to improve the known MP requirements of periparturient animals, enabling the extent and the consequences of periparturient BIP to be minimised.
\end{abstract}

\section{Nutrient partitioning around parturition: Immunity to parasites:} Protein requirements of sheep

The physiological processes that underlie the reproductive cycle impose considerable nutrient demands on a female. For example, energy and protein requirements can increase between two- and tenfold during lactation (Blaxter, 1989; Jessop, 1997), levels that are rarely encountered during the rest of an animal's life. This demand is serviced in many ways, e.g. quantity of food consumed increases and nutrients may be mobilised from sites within the female's body. In addition, changes in metabolic activities of tissues, e.g. brown adipose tissue, can spare nutrients for reproductive processes (Trayhurn, 1985). Nutrients are not only needed for reproductive functions during a reproductive cycle, but also for the so-called maintenance functions, which include resting metabolism and thermoregulation.
Nutrient use for the former is obligatory to sustain life and may increase as the mass of active tissue increases with development of the uterus and mammary gland. Thermoregulatory costs are likely to be reduced when compared with those of a non-pregnant non-lactating animal, due to the increased heat production associated with reproduction.

Traditionally, immune functions have been regarded as part of maintenance. However, there is an increasing body of evidence that at least some aspects of immunity are sensitive to changes in nutrient supply (Coop \& Holmes, 1996; van Houtert \& Sykes, 1996; Coop \& Kyriazakis, 1999, 2001). It has been suggested that such evidence allows immune functions to be considered separately from maintenance functions, which are expected to be relatively 
Table 1. Examples of studies on periparturient breakdown of acquired immunity to parasites in species other than small ruminants

\begin{tabular}{llc}
\hline Host & Parasite & Reference \\
\hline Pig & Oesophagostomum dentatum, Hyostrongylus rubidus & Kloosterman et al. (1984) \\
Cow & Ostertagia ostertagi & Molina et al. (1999) \\
Rabbit & Andrya cuniculi, Trichostrongylus retortaeformis, Nematodiroides zembra & Lloyd et al. (1983) \\
Dog & Toxocara canis & Connan (1972) \\
Rat & Nippostrongylus brasiliensis & Ngwenya (1977) \\
Mouse & Trichinella spiralis & Selby \& Wakelin (1975) \\
& Trichuris muris & van Zon \& Eling (1980) \\
Horse & Glasmodium berghei & Xiao \& Herd (1994) \\
Deer & Ostertagia spp., Chabertia spp., Oesophagostomum spp. & Lancaster \& Andrews (1991) \\
Man & Plasmodium falciparum (1983) & \\
\hline
\end{tabular}

insensitive to (moderate) changes in nutrient supply (Coop \& Kyriazakis, 1999). An increasing number of experimental studies indicate that there may be competition for nutrient resources between the immune system and the reproductive effort (developing conceptus or mammary gland). As a consequence, immune functions may be penalised and a breakdown of immunity to parasites (BIP) can occur. As such, periparturient BIP may have a nutritional basis.

In the present review we begin by briefly referring to a recently-developed nutrient-partitioning framework, which introduced the nutritional basis for periparturient BIP (Coop \& Kyriazakis, 1999). We will also summarise the immune responses involved in the expression of acquired immunity to gastrointestinal nematodes. We then explore the nutritional basis of periparturient BIP, initially in a qualitative descriptive way, and then in a more quantitative way. We will focus on periparturient sheep infected with the abomasal nematode Teladorsagia circumcincta, as sheep usually show a clear and repeatable periparturient breakdown of immunity to this parasite (O'Sullivan \& Donald, 1973; Leyva et al. 1982; Jackson et al. 1988). However, periparturient BIP is not limited to sheep infected with this specific nematode, but is more likely to be a general phenomenon in mammals (Table 1). We will also focus on the role of metabolisable (available) protein (MP) as a scarce nutrient, although it might be argued that similar concepts could apply to other nutrients. It is less likely that BIP results from competition for metabolisable energy; changes in the supply of metabolisable energy did not affect BIP in sheep (Bown et al. 1991; Donaldson et al. 1998). Last, we will briefly broaden the nutritional basis of BIP to other nutrients, other hosts and other parasites.

\section{A nutrient-partitioning framework}

The principles of the nutrient-partitioning framework have been drawn from the idea of evolutionary fitness, and relate to the perceived goals of parasitised animals for nutrient allocation in terms of survival and reproductive fitness when nutrient resources are scarce (Coop \& Kyriazakis, 1999). These authors have argued that animals will be expected to give the highest priority to the allocation of scarce nutrients for maintenance functions, as this action will guarantee survival of individuals in the short term. The second-highest priority for scarce nutrient allocation would be for reproductive effort, as this will ensure survival of the species in the long term. The high priority for maintenance and reproductive effort imply that immune functions, and especially those associated with the expression of acquired immunity to parasites, have a relatively low priority for the allocation of scarce nutrients in comparison with reproductive effort (Coop \& Kyriazakis, 1999). In other words, at times of nutrient scarcity, the penalty on expression of immunity would be expected to be greater than that on reproduction. Had immunity been given a higher priority than reproduction for the allocation of scarce nutrients, then the penalty on reproduction would be expected to be greater than that on expression of immunity. For example, parasitised ewes would then be expected to give birth to lighter lambs than non-parasitised ewes. The latter does not seem to be the case (Leyva et al. 1982; Thomas \& Ali, 1983).

\section{Expression of acquired immunity to gastrointestinal nematodes}

The expression of acquired immunity to gastrointestinal nematodes has been studied extensively in rodents (Rothwell, 1989; Else \& Finkelman, 1998; Claerebout \& Vercruysse, 2000). Briefly, on activation, specific $\mathrm{T}$ lymphocytes (T-helper 2 cells) produce cytokines, which induce inflammatory responses (e.g. eosinophilia, mucosal mastocytosis and globlet cell hyperplasia) in gut epithelium (cellular immune response). Mucus from globlet cells can paralyse the nematodes. Mast cells release a range of compounds, including proteases, and then transform into globule leucocytes. These proteases break down junctions between epithelial cells, causing increased permeability, allowing molecules from the systemic circulation to leak into the lumen. This process may facilitate parasite expulsion through the development of a microenvironment detrimental to parasite survival. In addition to this cellular immune response there is a humoral immune response, with production of parasite-specific immunoglobulins (Ig; IgA, $\mathrm{IgG}_{1}$ and $\left.\mathrm{IgE}\right)$. These Ig play an important role in mast cell activation (IgE), may directly bind to nematodes (IgA) and mediate in physical entrapment of the nematode in superficial mucus $\left(\mathrm{IgG}_{1}\right)$.

Most of these cellular and humoral effector mechanisms in rodents may operate in ruminants as well, although nematode expulsion in ruminants is less well understood (Claerebout \& Vercruysse, 2000). For example, the involvement of T-helper 2 cells has not been shown in ruminants. 
The amounts of circulating or local lymphocytes and Ig, as well as globlet cell- and globule leucocyte hyperplasia, usually, but not necessarily, correlate positively with nematode expulsion (Claerebout \& Vercruysse, 2000). The reasons why some studies do observe such correlations between different effector arms of the immune system (cellular $v$. humoral) and nematode expulsion, whilst others do not, are not well understood, but a potential role for nutrient availability cannot be excluded.

\section{Periparturient breakdown of acquired immunity to gastrointestinal nematodes in sheep}

The expression of acquired immunity to gastrointestinal nematodes in adult ewes is usually highly effective; the majority of the incoming infective larvae, which are ingested during grazing contaminated pastures, are either rapidly rejected or their development is inhibited. Inhibited larvae may lay dormant in the mucosa for many months. Thus, adult ewes usually harbour a small number of adult nematodes which produce eggs that are excreted in the faeces of the host. As a consequence, the number of nematode eggs in their faeces (faecal egg count; FEC) is often low or zero (Yakoob et al. 1983; Gibbs \& Barger, 1986). However, FEC are often temporarily elevated during the periparturient period; this finding was first reported about 70 years ago (Taylor, 1935). It has long been suspected that a transient reduction in immunity causes the increased FEC around parturition (Crofton, 1954). The consequences of this BIP in sheep have been well documented. Parasitised periparturient ewes usually carry more adult nematodes, excrete more nematode eggs via the faeces and have less mucosal mast cells and globule leucocytes in the gastrointestinal mucosa than parasitised non-reproducing ewes. We will argue that these consequences are likely to have originated from a scarce supply of MP.

\section{A nutritional basis for periparturient breakdown of immunity to parasites: scarcity of metabolisable protein}

Many of the components of the immune system, such as Ig, cytokines and mast cell protease, are proteinaceous in nature (Lewis \& Austen, 1981; MacRae, 1993; Coop \& Holmes, 1996). This factor implies that a certain amount of MP would be required to mount and maintain an effective immune response. Thus, scarcity of MP supply to the immune system may result in BIP. Such scarcity would be expected to occur especially at times when prioritised bodily functions have high protein demands, such as reproductive effort during the periparturient period (Coop \& Kyriazakis, 1999).

It can be hypothesised that an increased supply of, or a decreased demand for, MP reduces the periparturient BIP. Recent outcomes of protein supplementation studies in parasitised periparturient sheep (Donaldson et al. 1998; Kahn et al. 1999; Houdijk et al. 2000, 2001a,b) and parasitised lactating goats (Chartier et al. 2000) support this view. Protein supplementation resulted in decreased FEC and worm burden, and an increased concentration of globule leucocytes in the abomasal mucosa of periparturient ewes.
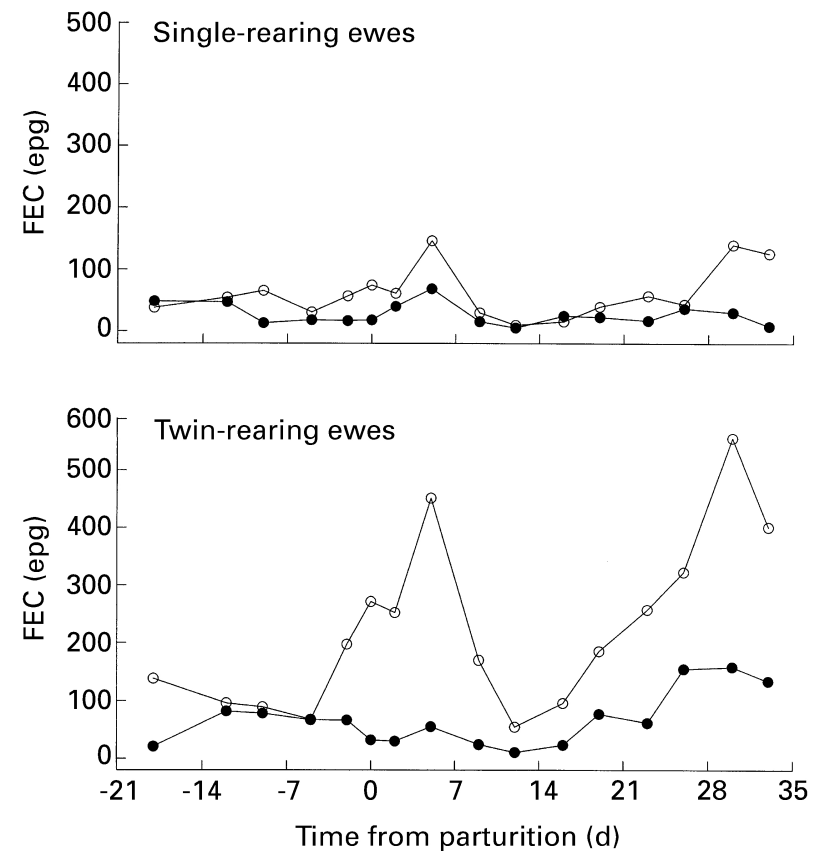

Fig. 1. Backtransformed mean faecal egg count (FEC, expressed as no. of nematode eggs per $\mathrm{g}$ faeces (epg)) of single- or twin-rearing ewes fed ad libitum foods that were calculated to provide either scarce (o) or adequate $(\bullet)$ amount of metabolisable protein. The ewes were infected with Teladorsagia circumcincta at a rate of 100003 rd stage infective larvae per d for $3 \mathrm{~d}$ per week from day -49 onwards. (Redrawn from Houdijk et al. 2001a.)

In addition, parasitised single-rearing ewes and goats usually have lower FEC and smaller worm burdens than their twin-rearing counterparts (Romjali et al. 1997; Baker et al. 1998; Donaldson et al. 1998; Houdijk et al. 2001a). High-yielding dairy goats may have a higher extent of BIP than low-producing goats (Hoste \& Chartier, 1993; Chartier et al. 2000). Similar effects may be expected from genetic selection for an increased reproductive effort (Rauw et al. 1998).

In contrast, changes in supply of, and demand for, MP do not always affect periparturient BIP, although these contradictions can be explained. For example, feeding foods that were calculated to limit MP supply did not affect periparturient BIP in ad libitum-fed single-rearing ewes infected with T. circumcincta (Fig. 1; Houdijk et al. 2001a). However, feeding the same food to their twin-rearing counterparts resulted in periparturient BIP. The single-rearing ewes achieved higher than expected levels of food intake in this experiment. In contrast to the twin-rearing ewes, an increased MP supply did not improve performance of the single-rearing ewes (e.g. milk production). This finding implied that the single-rearing ewes were not limited by MP, even when fed the scarce-MP food. These results suggest that, if hosts are able to do so, increased feed intake may overcome BIP to a certain extent.

The effect of changes in supply of dietary MP on periparturient BIP may also depend on the presence of labile body protein (protein reserves), which may act as an endogenous source of MP (Jessop, 1997). We have recently shown that body protein may overcome the consequences of dietary MP 


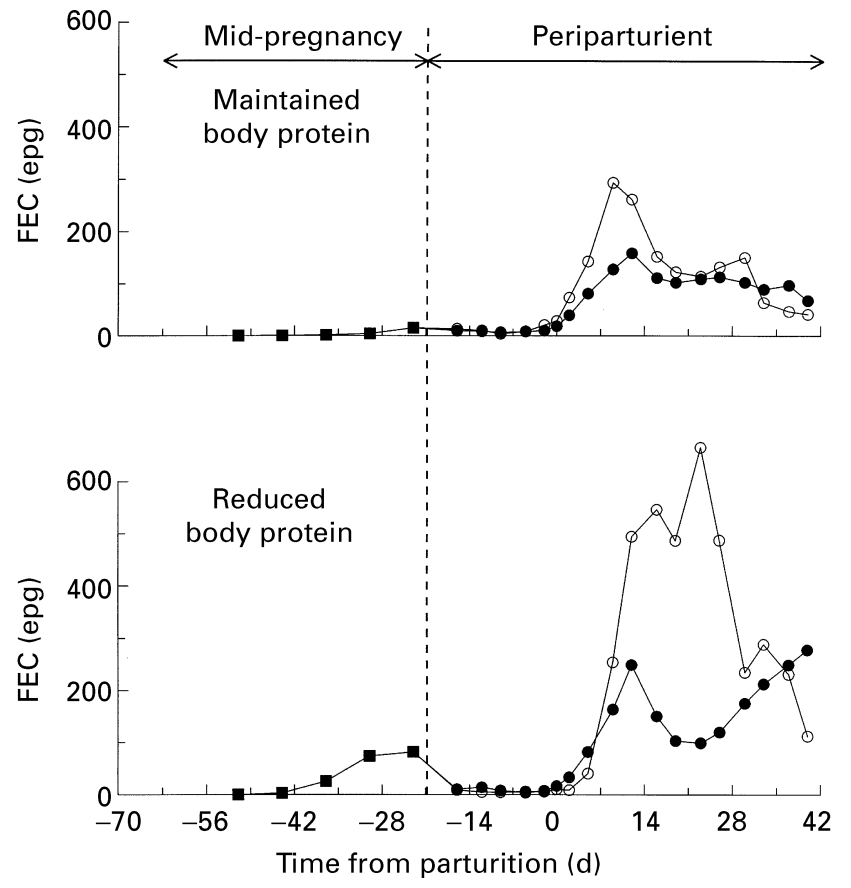

Fig. 2. Backtransformed mean faecal egg count (FEC: expressed as no. of nematode eggs per $g$ faeces (epg)) of twin-bearing and -rearing ewes offered a scarce $(\circ)$ or adequate $(\bullet)$ amount of metabolisable protein during the periparturient period, following midpregnancy feeding strategies to (a) maintain or (b) reduce body protein. The ewes were infected with Teladorsagia circumcincta at a rate of 10000 3rd stage infective larvae for $3 \mathrm{~d}$ per week from day -63 onwards. (Redrawn from Houdijk et al. 2001b.)

scarcity on periparturient BIP (Fig. 2; Houdijk et al. 2001b). Periparturient dietary MP scarcity did not affect periparturient BIP in ewes infected with $T$. circumcincta when the ewes were fed to maintain body protein during midpregnancy. In contrast, dietary MP scarcity exaggerated the extent of periparturient BIP in similarly-infected ewes fed to reduce body protein during mid-pregnancy.

Nutrient allocation to reproductive and immune functions has so far been dealt with in a qualitative descriptive way. This approach was considered a logical first step, i.e. to identify whether a nutritional basis of periparturient BIP existed in the first place. There is now a growing body of evidence in favour of the existence of the latter, and some apparent contradictions have been accounted for. We next wish to quantitatively explore this nutritional basis of periparturient BIP, by addressing MP requirements for expression of immunity to parasites in relation to MP requirements for reproduction.

\section{Metabolisable protein requirements for reproduction}

In qualitative terms, certain generalisations can be made as to the pattern of MP requirements during a reproductive cycle across mammals. During pregnancy there is an MP requirement for growth of the fetus, uterus, placenta and mammary gland. During lactation MP is required for continuing development of the mammary gland and for the production of milk. Quantitatively it is more difficult to generalise, since different reproductive strategies have

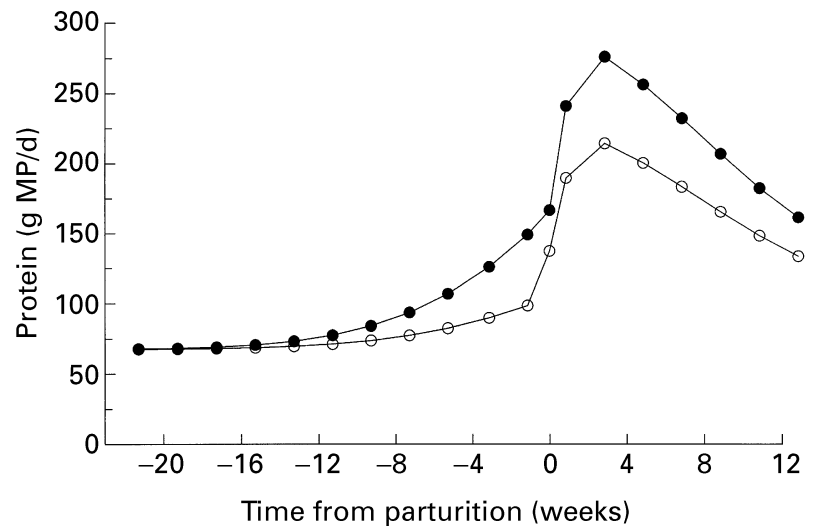

Fig. 3. Estimated metabolisable protein (MP) requirements of a $60 \mathrm{~kg}$ ewe bearing and rearing singles $(\circ)$ or twins $(\bullet)$. (Calculated from Agricultural and Food Research Council, 1993; Groenewald et al. 1996.)

evolved for different species. These strategies vary in the relative effort invested in pregnancy with respect to lactation, seen in the extent of development of the young at parturition, as well as in the length and intensity of lactation.

The MP requirements during the reproductive cycle have been well characterised for farm animals. Fig. 3 shows such data for a $60 \mathrm{~kg}$ sheep bearing and rearing one or two lambs. Depending on litter size, MP requirements increase to three to four times that of non-pregnant and non-lactating animals, with a maximum of approximately $13 \mathrm{~g} \mathrm{MP} / \mathrm{kg}$ metabolic body weight (body weight ${ }^{0.75}$ ) per $\mathrm{d}$. The physiological changes that arise from attempting to meet the increased MP requirements are major. The increased voluntary intake leads to hypertrophy of the gut (Hammond \& Diamond, 1992) and increases in cardiac output and blood flow to the gut and mammary gland (Sakanashi et al. 1987). These factors, together with hormonal changes (Bauman, 2000), result in an increase in potential MP supply to the mammary gland. For some animals these changes ensure sufficient supply of MP to meet the increased requirement of lactation. However, in many circumstances MP supply falls short of that required, e.g. due to the maximum amount of food offered, maximum rate at which food can be processed, or the nutritional quality of the food. To some extent, MP supply from body protein may overcome this shortfall.

With regard to MP supply from body protein, Naismith \& Morgan (1976) proposed a biphasic nature to protein use during gestation. Protein would accumulate in the body during the first half of pregnancy, and be drawn upon (thus acting as a reserve), when needed during the latter half of pregnancy and during early lactation. This process has been shown to take place in rats (Naismith et al. 1982), human subjects (Motil et al. 1989) and cattle (Trigg \& Topps, 1981). It has been estimated that at times when protein reserves are present up to approximately $25 \%$ of the body protein, principally from muscle and skin, can be mobilised (Botts et al. 1979; Pine et al. 1994b). Net fractional rates of loss of such labile protein can be as high as $13 \% / \mathrm{d}$ during early lactation in rats (Pine et al. 1994a). Allowing for differences in metabolic time, this rate of loss would be equivalent to a protein loss of approximately $2.5 \mathrm{~g} / \mathrm{kg}$ body 
weight $^{0.75}$ per $\mathrm{d}$ in sheep, potentially meeting about $20 \%$ of the maximum MP requirements of lactating sheep.

Coop \& Kyriazakis (1999) have suggested that animals give the highest priority of scarce MP allocation to maintenance, defined as maintenance of body protein (Emmans \& Fisher, 1986). However, we have discussed that animals may lose body protein to support reproductive and immune functions at times of dietary MP scarcity (Jessop, 1997; Houdijk et al. 2001 b). Dividing body protein into that which is essential for tissue integrity and that which can potentially be mobilised may solve this paradox. We would propose that maintenance of essential body protein is given the highest priority for scarce nutrient allocation, whilst the maintenance of labile body protein would get a low priority, lower than that for reproductive and immune functions.

\section{Metabolisable protein requirement for expression of immunity}

The estimation of MP requirements for expression of immunity to gastrointestinal nematodes may be derived by comparing whole-animal quantities of effector cells and/or molecules in non-infected naive sheep and infected immune sheep. This estimation will be done for sheep expressing immunity to $T$. circumcincta. We have based this estimation on quantitative data relating to circulating lymphocytes and $\mathrm{Ig}$, mucosal mast cells and sheep mast cell proteases, and plasma loss (see Table 2). Our estimation of the MP requirement for the expression of immunity to T. circumcincta in sheep is based on several assumptions related to the conversion of the data obtained to wholeanimal quantities, protein contents and half-life of effector cells and/or molecules, and the efficiency for protein synthesis from MP supply (Table 2). Accurate measurements to confirm or improve these assumptions are required. We also wished to include MP requirements for mucus production. It is well known that the secretion of mucus plays an important role in the expression of immunity to gastrointestinal nematodes (Miller, 1984), and the amount of mucus produced per d may be considerable. However, appropriate quantitative data to estimate the latter are not (yet) available.

A series of measurements were taken from the gastric lymph of sheep infected with $T$. circumcincta (Smith et al.
1981, 1983, 1984). At a systemic level, the most pronounced differences between infected immune sheep and parasitefree sheep were an increased concentration of lymphocytes and $\operatorname{IgA}$ in the gastric lymph. It was calculated that the amount of MP required to maintain this difference would be about $50 \mathrm{mg} / \mathrm{kg}$ body weight ${ }^{0.75}$ per d (Table 2). At a local level, in the mucosa of the gut wall one of the most striking aspects of expression of immunity to gastrointestinal nematodes is mucosal mast cell hyperplasia and the release of sheep mast cell protease (Miller, 1984). Our estimations suggest that the associated demand for MP is $<1 \mathrm{mg} / \mathrm{kg}$ body weight ${ }^{0.75}$ per $\mathrm{d}$.

One of the key features of an infection with gastrointestinal nematodes is the leakage of considerable quantities of plasma into the gastrointestinal tract (Holmes, 1993). Whilst this factor has long been thought to be associated with primary infections, substantial plasma leakage has also been measured in solidly-immune sheep challenged with T. circumcincta (Yakoob et al. 1983). These sheep had low FEC and few adult nematodes present at slaughter, but had almost twice as much plasma leakage as their non-infected counterparts. Thus, although the concept is perhaps controversial, we have considered plasma leakage as an integral part of the expression of immunity to gastrointestinal nematodes. Plasma leakage may be seen as a mechanism for the delivery of circulating Ig and other compounds to the site of infection (Miller, 1996). A large amount of the lumen $\mathrm{N}$ originating from plasma leakage can be expected to be salvaged in more distal parts of the gastrointestinal tract (Kimambo et al. 1988; Jackson, 1998). However, such salvaged $N$ may to some extent be excreted in the urine, presumably after being broken down to $\mathrm{NH}_{3}$ and converted into urea (Taylor et al. 1989). In addition, it has also been shown that such $\mathrm{N}$ leakage matched a decreased $\mathrm{N}$ retention in growing sheep (Rowe et al. 1988). Thus, we have considered all plasma $\mathrm{N}$ leakage into the gut as an irreversible loss which needs to be replenished, resulting in an estimated MP requirement approximately $650 \mathrm{mg} / \mathrm{kg}$ body weight ${ }^{0.75}$ per d (Table 2). This value may be an underestimation. Plasma leakage remains to be determined in parasitised periparturient animals in which blood flow rate through the gut, and hence the potential for plasma leakage, may be increased compared with non-reproducing animals.

Table 1. Estimation of the requirement for metabolisable protein (MP) to maintain the expression of immunity to Teladorsagia circumcincta in sheep*

\begin{tabular}{lccc}
\hline & Parasite-free sheep & Infected immune sheep & Requirement for MP $(\mathrm{mg} / \mathrm{kg} \mathrm{MBW} \mathrm{per} \mathrm{d)}$ \\
\hline Total cell flow in lymph (no. of cells/d) & $6.9 \times 10^{9}$ & $21.8 \times 10^{9}$ & 19.8 \\
Flow of IgA in lymph (mg/d) & 36 & 888 & 32.5 \\
Mucosal mast cells (no. of cells/0.2 mm ${ }^{2}$ ) & $54 \times 10^{6}$ & $345 \times 10^{6}$ & 0.3 \\
Sheep mast-cell proteases $(\mu \mathrm{g} / \mathrm{g}$ tissue) & 0.5 & $171 \cdot 7$ & 0.2 \\
Plasma loss (ml/d) & 40 & 190 & $655 \cdot 3$ \\
Total & & & $708 \cdot 1$ \\
\hline
\end{tabular}

MBW, metabolic body weight (body weight $\left.{ }^{0.75}\right)$; Ig, immunoglobulin.

*Compiled from Smith et al. (1981, 1983, 1984), Yakoob et al. (1983), Huntley et al. (1987) and Parkins \& Holmes (1989).

†The following assumptions were made, or taken from Fell et al. (1972), Frandson (1986), Agricultural and Food Research Council (1993) and Klasing \& Calvert (1999): Iymph represents $10 \%$ total blood volume, packed cell volume of blood is 0.33 , blood volume is $8 \%$ body weight, immune cells weigh $2 \times 10^{-10} \mathrm{~g}$ and contain $18 \%$ protein, half-life of IgA and lymphocytes is $7 \mathrm{~d}$, half-life of mucosal mast cells is $1.5 \mathrm{~d}$, efficiency for protein synthesis is 0.85 , plasma contains $60-75 \mathrm{~g}$ protein/l, abomasum volume is 1.4 litres, abomasal folds and glands increase the abomasal surface by a factor of 10 , the abomasum weighs $250 \mathrm{~g}$ of which $20 \%$ is mucosa. 
Without taking into account the MP requirement for mucus production, the MP requirement for the expression of immunity to $T$. circumcincta in sheep was estimated to be approximately $0.7 \mathrm{~g} / \mathrm{kg}$ body weight ${ }^{0.75}$ per $\mathrm{d}$, which is about $5 \%$ of the maximum MP requirements for the non-infected twin-rearing ewe. This value indicates that the potential supply of protein from labile body protein (see p. 518) is probably sufficient to meet the MP requirement for the expression of immunity to $T$. circumcincta. The latter confirms our previously-discussed findings that body protein may overcome effects of MP scarcity on BIP in periparturient ewes infected with $T$. circumcincta (Houdijk et al. 2001b).

Our estimate of MP requirements for expression of immunity to $T$. circumcincta may be relatively small, but may need to be drawn from a much larger pool of MP if the required amino acid profile differs from that supplied. We have assumed that protein supply and demand are in balance in terms of amino acid composition. For ruminants, the amino acid composition of MP is still uncertain and, at present, there is only limited information available on the amino acid composition of proteins involved in the expression of immunity. For example, it has been suggested that immune cells have a relatively high requirement for glutamine (Calder, 1995) and for cysteine and methionine (MacRae, 1993; Takahashi et al. 1997; Dröge \& Breitkreutz, 2000). Likewise, a relatively large amount of phenylalanine and tryptophan is required for the acute-phase protein response which is usually associated with responses to systemic infections or trauma (Reeds et al. 1994).

Our estimate of the MP requirement for the expression of immunity to $T$. circumcincta suggests that the MP requirements for parasitised periparturient ewes rearing twins may be about $5 \%$ higher than current estimates of protein requirements for non-infected ewes (Agricultural and Food Research Council, 1993). This value is somewhat lower than that of about 20\% suggested elsewhere (Sykes, 2000). Whilst our estimate may well be an underestimation, the latter was derived from experiments that were not designed to assess nutrient requirements, and as a consequence may be an overestimation due to the assumption that the highest level of MP supplied via the diet was equal to the MP requirement. Although arbitrary, we would suggest that periparturient BIP may largely be overcome by increasing the MP supply by about $10 \%$. However, there is no accurate data-set available (yet) that uses a sufficient number of appropriately chosen levels of dietary MP supply with which we could confirm these estimates. Currently, we are performing an experiment in which periparturient ewes infected with $T$. circumcincta are fed at $65,80,95,110$ or $125 \%$ of the MP requirements. Such experiments will provide data to confirm estimates for the MP requirements of infected periparturients ewes and to model MP allocation to reproductive effort and to immunity to $T$. circumcincta. The optimal level of dietary MP intake for maximum expression of immunity in periparturient animals is expected to be higher than that for reproductive effort only (Fig. 4). This difference stems from the hypothesis that expression of immunity has a lower priority for the allocation of scarce nutrients than reproductive effort (Coop \& Kyriazakis, 1999).

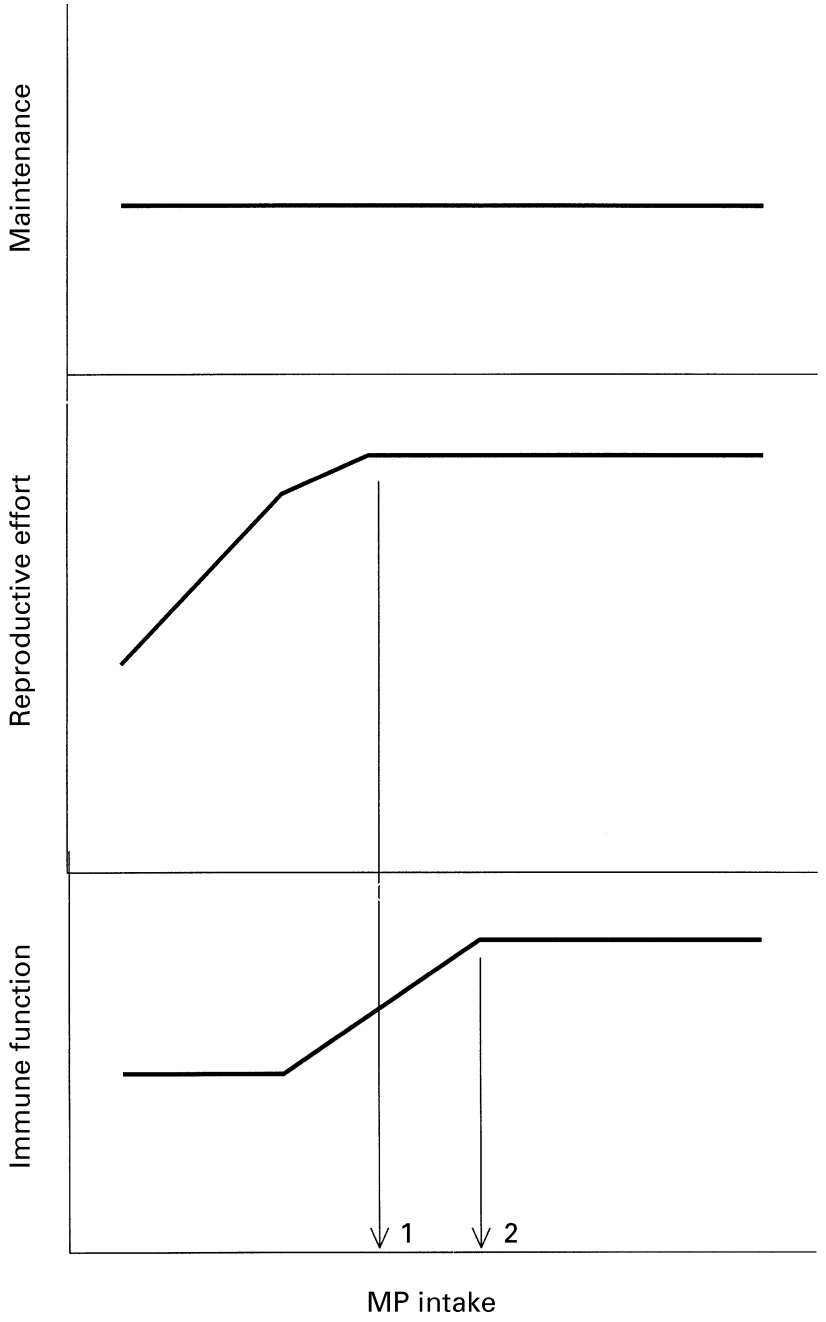

Fig. 4. Conceptual framework for the partitioning of metabolisable protein (MP) to maintenance functions, reproductive effort and immune functions. Maximal reproductive effort is reached at 1 and minimum breakdown of immunity to parasites is reached at 2 . The latter would be the estimated MP requirements of the parasitised periparturient animal.

Our estimation of the MP requirement for the expression of immunity to gastrointestinal parasites may be used to test the nutrient-partitioning framework on which our initial hypotheses were based. Coop \& Kyriazakis (1999) proposed that the majority of scarce MP would be allocated to the prioritised reproductive effort rather than to immune functions. A consequence of the resulting BIP is that parasite burden and tissue damage increase. Since tissue damage may hamper maintenance functions, scarce nutrient allocation to tissue repair is expected to have a high priority (Coop \& Kyriazakis, 1999). However, if the host aims to prioritise scarce nutrient allocation to its reproductive effort, then the nutrient requirement for the repair of tissue damage would need to be lower than the nutrient requirement for the expression of immunity to parasites. MP requirements for tissue repair following a $T$. circumcincta infection are unknown, but may be derived from measurements of the amino acid metabolism of the infected gastrointestinal tract, as recently done by $\mathrm{Yu}$ et al. (2000) for another type of 
parasitic infection. To allocate such measurements to tissue repair, data should be obtained during the first few weeks of infection, i.e. before the expression of immunity starts to occur.

We have estimated the MP requirement for the expression of immunity in a specific case, i.e. immunity to $T$. circumcincta in sheep. Data from chickens challenged with lipopolysaccharides, which are antigenic components of bacterial cell walls, may be used to estimate MP requirements for immunity to other types of infections (Klasing \& Calvert, 1999). These authors estimated that the immune response following a lipopolysaccharide challenge required lysine at a rate of approximately $435 \mu \mathrm{mol} / \mathrm{kg}$ body weight per d. Quantitatively, the most important host response to such a challenge is an increase in plasma acute-phase proteins, which contain on average $7 \%$ lysine (Reeds et al. 1994). It can be calculated that the MP requirement for immune responses to a lipopolysaccharide challenge in chickens is about $0.8 \mathrm{~g} / \mathrm{kg}$ body weight ${ }^{0.75}$ per $\mathrm{d}$. In addition, protein loss over a range of infections in man was also of the same order (Powanda, 1977). Although more data are needed for confirmation, these estimations suggest that host MP requirements for the expression of immunity to a wide range of infections may all be of the same order of magnitude, despite the different underlying immune mechanisms.

\section{Broadening the nutritional basis for breakdown in immunity: other nutrients, other hosts and other parasites}

In the present review we have focused on MP scarcity as a cause of breakdown of immunity to $T$. circumcincta in periparturient sheep. However, there are no reasons why the concepts could not be expanded to other nutrients, other hosts and other parasites. For example, several other nutrients are known to influence immune functions, including vitamins (e.g. vitamin A), minerals (e.g. Zn and $\mathrm{Fe}$ ) and fatty acids (Chandra, 1997; Miles \& Calder, 1998). In theory, scarcity of any of these nutrients may cause some extent of BIP. We would argue that the importance of nutrients in causing BIP depends on which nutrient will be first limiting for the expression of immunity. However, it should be noted that since isolated deficiencies of nutrients are rare (Chandra, 1997), an increased supply of a specific nutrient may not necessarily overcome BIP.

In contrast to changes in MP supply, BIP in sheep is unlikely to be influenced by (moderate) changes in the metabolisable energy supply (Bown et al. 1991; Donaldson et al. 1998). This contradiction between metabolisable energy and MP is not well understood. Effects of energy or protein nutrition may be difficult to appreciate in isolation, since changes in energy and protein nutrition are often correlated. This issue could be readily elucidated in parasitised rodents. In contrast to ruminants, it is relatively easy to feed single-stomached animals isoenergetic foods with different protein contents as well as isonitrogenous foods that supply different amounts of non-protein energy. Such foods have recently been used to distinguish the effects of protein and non-protein energy on mammary activity in lactating rats (Goodwill et al. 1996).
It has been shown repeatedly that in growing sheep protein supplementation enhances the expression of immunity, resulting in decreased FEC and increased nematode expulsion (for references, see Coop \& Kyriazakis, 1999, 2001). Similar examples can be found in growing goats (Papadopoulos et al. 2000), rats (Cummins et al. 1987) and mice (Boulay et al. 1998). It might be argued that their non-supplemented counterparts, in which the expression of immunity is penalised, experience some extent of breakdown of the potential expression of immunity to parasites. For example, van Houtert et al. (1995) observed that the concentrations of eosinophils in the blood and mucosal mast cell proteases in the gut were lower in nonsupplemented, parasitised growing sheep than in their protein-supplemented counterparts. However, compared with non-infected controls, the non-supplemented parasitised sheep had higher concentrations of both blood eosinophils and gut mast cell proteases. This finding indicates that the potential for expression of immunity was present in the parasitised sheep, although MP scarcity may have reduced its effectiveness.

Another example of BIP in growing animals is the socalled type II ostertagiosis. This condition can be observed in calves housed for the winter after their first grazing season (Berghen et al. 1990). During type II ostertagiosis inhibited larvae suddenly re-emerge, with pathophysiological consequences for the host. It is a quite common agricultural practice to keep winter-housed calves on a relatively low plane of nutrition. Under such conditions body reserves form an additional source of nutrients for the host. It might be hypothesised that as long as a certain level of body reserves are present BIP would not occur, since MP requirements for the expression of immunity may be met from mobilised body protein (see p. 520). Timing and severity of bovine type II ostertagiosis in housed calves on a low plane of nutrition may thus depend on body condition in general, and labile body protein in particular.

Recent observations on interactions between parasitism, nutrition and reproductive effort in breeding birds support the nutritional hypothesis for the occurrence of BIP at times of high nutrient demands for the reproductive effort. An increased food supply (voles, Microtus agrestis) resulted in a decreased level of parasitism in nestling owls such as tawny owls (Strix aluco; Appleby et al. 1999) and in kestrels (Falco tinnunculus; Wiehn \& Korpimaki, 1998). An increased brood size resulted in an increased prevalence of haematozoan parasites in great tits (Parus major; Norris et al. 1994; Richner et al. 1995), and reduced ability to mount an antibody response to Newcastle disease virus vaccine in the collared fly catcher (Ficedula albicollis; Nordling et al. 1998). It has been shown also that the negative correlation between brood size and susceptibility to Trypanosoma spp. in Tengmalm's owls (Aegolius funereus; Ilmonen et al. 1999) and in kestrels (Wiehn et al. 1999) was present only at times of moderate vole supply and not at times of vole abundance. Although these observations support the nutritional basis for BIP, it is highly unlikely that protein scarcity is the causal factor in the case of vole-eating owls.

Whilst BIP has been extensively reported for growing and periparturient animals, BIP in adult non-periparturient 
animals have only been reported sporadically. For example, Poelvoorde (1973) reported on rising FEC in housed adult boars. In contrast, it is well known that protein-energy malnutrition forms at least part of the basis of the reduced immunity in elderly human subjects (Chandra, 1991). However, effects of ageing and mal-nutrition are often confounded. MP scarcity in adult non-reproducing animals may be difficult to induce due to the presence of labile body protein. The latter may be the reason why BIP is not easily observed in adult non-reproducing animals. A study with mature animals that have been fed at a level designed to reduce body protein would provide a strong test for the existence of a nutritional basis for BIP; can BIP be induced in immune non-reproducing adult animals by feeding a limiting amount of MP?

Finally, there is evidence that the extent of periparturient BIP differs between species of gastrointestinal nematodes in sheep (O'Sullivan \& Donald, 1970, 1973; Gibbs \& Barger, 1986; Jackson et al. 1988; Barger, 1993). In general, periparturient sheep show a more pronounced breakdown of immunity to the abomasal nematode $T$. circumcincta than to Trichostrongylus spp. (nematodes that reside in the small intestine). In addition, a breakdown of immunity towards the small intestinal nematode Nematodirus spp. does not seem to occur at all. The reason for such differences in the extent of BIP between nematodes and their underlying mechanisms are unclear. Possible explanations may lie in the site of infection (abomasum $v$. small intestine) and the type of immune response evoked. Aspects to explore may include a possible higher priority for the host to maintain a certain degree of immunity in the small intestine, since this site is also a preferred site of attachment or invasion for bacteria. In relation to the type of immune response, protein scarcity seems to affect non-specific defences and cellular immunity to a much larger extent than it affects humoral immunity (Calder \& Jackson, 2000). Future research would be needed to establish if, and to what extent, dependency on cellular immune responses differs between different parasites. A different extent of dependency on cellular immune responses may account, at least in part, for the different extent of periparturient breakdown of immunity to different parasite species. The latter may be extended to breakdown of immunity to bacteria, and may provide information that accounts for the suggestion that immunity to bacteria is much less labile than immunity to nematodes (Waller, 1993).

\section{Conclusion}

In the present review we have explored the concept of a nutritional basis for periparturient BIP, which was introduced in a recently developed nutrient-partitioning framework. According to this framework periparturient BIP could be due to reproductive functions taking priority over immune functions for the use of scarce nutrients. Such scarcity arises from an imbalance between nutrient supply and demand. It is hypothesised that an increased supply of, or a decreased demand for, nutrients lowers the extent of periparturient BIP. This view is supported by experimental evidence on changes in MP supply and demand in peri-parturient ewes infected with the abomasal nematode Teladorsagia circumcincta. From the limited information available we estimated that the MP requirement for the expression of immunity to this parasite is about $1 \mathrm{~g} \mathrm{MP} / \mathrm{kg}$ body weight ${ }^{0.75}$ per $\mathrm{d}$. This value needs to be confirmed, but it may be used to improve the known nutrient requirement of periparturient animals in order to minimise the extent and the consequences of periparturient BIP.

\section{Acknowledgements}

We wish to thank Jonathan Yearlsey, Spiridoula Athanasiadou and Ian Wellock for their comments on earlier versions of the manuscript. The European Commision (DG VI) project no. FAIR3 CT96 1485, a collaborative programme between Scotland, France, Greece and Spain, and the Biotechnology and Biological Science Research Council have supported part of the work presented. The Scottish Agricultural College receives support from the Scottish Executive, Environment and Rural Affairs Department.

\section{References}

Agricultural and Food Research Council (1993) Energy and Protein Requirements of Ruminants. Wallingford, Oxon: CAB International.

Appleby BM, Anwar MA \& Petty SJ (1999) Short-term and longterm effects of food supply on parasite burdens in tawny owls, Strix aluco. Functional Ecology 13, 315-321.

Baker RL, Mwamachi DM, Audho JO, Aduda EO \& Thorpe W (1998) Resistance of Galla and Small East African goats in the sub-humid tropics to gastrointestinal nematode infections and the peri-parturient rise in faecal egg counts. Veterinary Parasitology 79, 53-64.

Barger IA (1993) Influence of sex and reproductive status on susceptibility of ruminants to nematode parasitism. International Journal for Parasitology 23, 463-469.

Bauman DE (2000) Regulation of nutrient partitioning during lactation: homeostasis and homeorhesis revisited. In Ruminant Physiology: Digestion, Metabolism, Growth and Reproduction, pp. 311-328 [PB Cronjé, editor]. Wallingford, Oxon: CAB International.

Berghen P, Dorny P, Hilderson H, Vercruysse J \& Hollanders W (1990) Observations on parasitic gastroenteritis and parasitic bronchitis in calves over two grazing seasons. Veterinary Record 127, 426-430.

Blaxter KL (1989) Energy Metabolism in Animals and Man. Cambridge: Cambridge University Press.

Botts RL, Hemken RW \& Bull LS (1979) Protein reserves in the lactating dairy cow. Journal of Dairy Science 62, 433-440.

Boulay M, Scott ME, Conly SL, Stevenson MM \& Koski KG (1998) Dietary protein and zinc restrictions independently modify a Heligmosomoides polygyrus (Nematoda) infection in mice. Parasitology 116, 449-462.

Bown MD, Poppi DP \& Sykes AR (1991) The effect of postruminal infusion of protein or energy on the pathophysiology of Trichostrongylus colubriformis infection and body composition in lambs. Australian Journal of Agricultural Research 42, 253-267.

Calder PC (1995) Fuel utilisation by cells of the immune system. Proceedings of the Nutrition Society 54, 65-82.

Calder PC \& Jackson AA (2000) Undernutrition, infection and immune function. Nutrition Research Reviews 13, 3-29. 
Chandra RK (1991) Nutrition and immunity in the elderly. Nutrition Research Reviews 4, 83-95.

Chandra RK (1997) Nutrition and the immune system: an introduction. American Journal of Clinical Nutrition 66, 460S-463S.

Chartier C, Etter E, Hoste H, Pors I, Mallereau M-P, Broqua C, Mallet S, Koch C \& Massé A (2000) Effects of the initial level of milk production and of the dietary protein intake on the course of natural nematode infection in dairy goats. Veterinary Parasitology 92, 1-13.

Claerebout E \& Vercruysse J (2000) The immune response and the evaluation of acquired immunity against gastrointestinal nematodes in cattle: a review. Parasitology 120, S25-S42.

Connan RM (1967) Observations on the epidemiology of parasite gastro-enteritis due to Oesophagostomum spp. and Hydrostrongylus ribidus in the pig. Veterinary Record 80, 424-429.

Connan RM (1972) The effect of host lactation on a second infection of Nippostrongylus brasiliensis in rats. Parasitology 64, 229-233.

Coop RL \& Holmes PH (1996) Nutrition and parasite interaction. International Journal for Parasitology 26, 951-962.

Coop RL \& Kyriazakis I (1999) Nutrition-parasite interaction. Veterinary Parasitology 84, 187-204.

Coop RL \& Kyriazakis I (2001) Influence of host nutrition on the development and consequences of nematode parasitism in ruminants. Trends in Parasitology 17, 325-330.

Crofton HD (1954) Nematode parasite populations in sheep on lowland farms. 1. Worm egg counts in ewes. Parasitology 44, 465-477.

Cummins AG, Duncombe VM, Bolin TD, Davis AE \& Yong J (1987) The response of the small intestine of the proteindeficient rat to infection with Nippostrongylus brasiliensis. International Journal for Parasitology 17, 1445-1450.

Donaldson J, van Houtert MFJ \& Sykes AR (1998) The effect of nutrition on the periparturient parasite status of mature ewes. Animal Science 67, 523-533.

Dröge W \& Breitkreutz R (2000) Glutathione and immune function. Proceedings of the Nutrition Society 59, 595-600.

Else KJ \& Finkelman FD (1998) Intestinal nematode parasites, cytokines and effector mechanisms. International Journal for Parasitology 28, 1145-1158.

Emmans GE \& Fisher C (1986) Problems in nutritional theory. In Nutrient Requirements of Poultry and Nutritional Research, pp. 9-39 [C Fisher and $\mathrm{N}$ Boorman, editors]. London: Butterworths.

Fell BF, Campbell RM, Mackie WS \& Weekes TEC (1972) Changes associated with pregnancy and lactation in some extrareproductive organs of the ewe. Journal of Agricultural Science, Cambridge 79, 397-407.

Frandson RD, (1986) Anatomy and Physiology of Farm Animals. Philadelphia, PA: Lea \& Febiger.

Gibbs HC \& Barger IA (1986) Haemonchus contortus and other trichostrongylid infections in parturient, lactating and dry ewes. Veterinary Parasitology 22, 57-66.

Goodwill M, Jessop NS \& Oldham JD (1996) Mammary sensitivity to protein and energy intakes during lactation. Journal of Dairy Science 79, Suppl. 1, 154.

Groenewald PCN, Ferreira AV, van der Merwe HJ \& Slippers SC (1996) Application of Bayesian inference in the comparison of lactation curves of Merino ewes. Animal Science 62, 63-69.

Hammond KA \& Diamond J (1992) An experimental test for a ceiling on sustained metabolic rate in lactating mice. Physiological Zoology 65, 952-977.

Holmes PH (1993) Interactions between parasites and animal nutrition: the veterinary consequences. Proceedings of the Nutrition Society 52, 113-120.
Hoste H \& Chartier C (1993) Comparison of the effects on milk production of concurrent infection with Haemonchus contortus and Trichostrongylus colubriformis in high- and low-producing dairy goats. American Journal of Veterinary Research 54, 1886-1893.

Houdijk JGM, Kyriazakis I, Jackson F \& Coop RL (2001a) The relationship between protein nutrition, reproductive effort and breakdown in immunity to Teladorsagia circumcincta in periparturient ewes. Animal Science 72, 595-606.

Houdijk JGM, Kyriazakis I, Jackson F \& Coop RL (2001b) The expression of immunity to Teladorsagia circumcincta and its relationship to protein nutrition depend on body protein reserves. Parasitology 122, 661-672.

Houdijk JGM, Kyriazakis I, Jackson F, Huntley JF \& Coop RL (2000) Can an increased metabolizable protein intake affect the periparturient relaxation in immunity against Teladorsagia circumcincta in sheep? Veterinary Parasitology 91, 43-62.

Huntley JF, Gibson S, Brown D, Smith WD, Jackson F \& Miller HRP (1987) Systemic release of a mast cell proteinase following nematode infections in sheep. Parasite Immunology 9, 603-614.

Ilmonen P, Hakkarainen H, Koivunen V, Korpimaki E, Mullie A \& Shutler D (1999) Parental effort and blood parasitism in Tengmalm's owl: effects of natural and experimental variation in food abundance. Oikos 86, 79-86.

Jackson AA (1998) Salvage of urea-nitrogen in the large bowel: functional significance in metabolic control and adaptation. Biochemical Society Transactions 26, 231-236.

Jackson F, Jackson E \& Williams JT (1988) Susceptibility of the pre-parturient ewe to infection with Trichostrongylus vitrinus and Ostertagia circumcincta. Research in Veterinary Science 45, 213-218.

Jessop NS (1997) Protein metabolism during lactation. Proceedings of the Nutrition Society 56, 169-175.

Kahn LP, Knox MR, Gray GD \& Corbett JL (1999) Enhancing immunity to nematode parasites in pregnant and lactating sheep through nutrition and genetic selection. Recent Advances in Animal Nutrition, Australia 12, 15-22.

Kimambo AE, MacRae JC \& Dewey PJS (1988) The effect of daily challenge with Trichostrongylus colubriformis larvae on the nutrition and performance of immunologically-resistant sheep. Veterinary Parasitology 28, 205-212.

Klasing KC \& Calvert CC (1999) The care and feeding of an immune system: an analysis of lysine needs. In Protein Metabolism and Nutrition, pp. 253-264 [GE Lobley, A White and JC MacRae, editors]. Wageningen, The Netherlands: Wageningen Press.

Kloosterman A, Borgsteede F \& Eysker M (1984) The effect of experimental Ostertagia ostertagi infections in stabled milking cows on egg output, serum pepsinogen levels, antibody titres and milk production. Veterinary Parasitology 17, 299-308.

Lancaster MB \& Andrews SJ (1991) Observations on the output of nematode eggs in faeces and on the subsequent pasture infestation with third stage larvae produced by a herd of farmed red deer (Cervus elaphus). Veterinary Record 129, 549-551.

Lewis RA \& Austin KF (1981) Mediation of local homeostasis and inflammatory by leukotrienes and other mast cell-dependent compounds. Nature 293, 103-108.

Leyva V, Henderson AE \& Sykes AR (1982) Effect of daily infection with Ostertagia circumcincta larvae on food intake, milk production and wool growth in sheep. Journal of Agricultural Science, Cambridge 99, 249-259.

Lloyd S (1983) Effect of pregnancy and lactation upon infection. Veterinary Immunology and Immunopathology 4, 153-176.

Lloyd S, Amerasinghe PH \& Soulsby EJL (1983) Periparturient immunosuppression in the bitch and its influence on infection with Toxocara canis. Journal of Small Animal Practice 24, 237-247. 
MacRae JC (1993) Metabolic consequences of intestinal parasitism. Proceedings of the Nutrition Society 52, 121-130.

Miles EA \& Calder PC (1998) Modulation of immune function by dietary fatty acids. Proceedings of the Nutrition Society 57, 277-292.

Miller HRP (1984) The protective mucosal response against gastrointestinal nematodes in ruminants and laboratory animals. Veterinary Immunology and Immunopathology 6, 167-259.

Miller HRP (1996) Mucosal mast cells and the allergic response against nematode parasites. Veterinary Immunology and Immunopathology 54, 331-336.

Molina X, Casanova JC \& Feliu C (1999) Influence of host weight, sex and reproductive status on helminth parasites of the wild rabbit, Oryctolagus cuniculus, in Navarra, Spain. Journal of Helminthology 73, 221-225.

Motil KJ, Montandon CM, Hachey DL, Boutbon TW, Klein PD \& Garza C (1989) Relationships among lactational performance, maternal diet and body protein metabolism in humans. European Journal of Clinical Nutrition 43, 681-691.

Naismith DJ \& Morgan BLG (1976) The biphasic nature of protein metabolism during pregnancy in the rat. British Journal of Nutrition 36, 563-566.

Naismith DJ, Richardson DP \& Pritchard AE (1982) The utilization of protein and energy during lactation in the rat, with particular regard to the use of that accumulated in pregnancy. British Journal of Nutrition 48, 433-441.

Ngwenya BZ (1977) Response of nonsensitized and sensitized lactating mice to infection with Trichinella spiralis. International Journal for Parasitology 7, 41-45.

Nordling D, Andersson M, Zohari S \& Gustafsson L (1998) Reproductive effort reduces specific immune response and parasite resistance. Proceedings of the Royal Society of London 265, $1291-1298$.

Norris K, Anwar M \& Read AF (1994) Reproductive effort influences the prevalence of haematozoan parasites in great tits. Journal of Animal Ecology 63, 601-610.

O'Sullivan BM \& Donald AD (1970) A field study of nematode parasite populations in the lactating ewe. Parasitology 61, 301-315.

O'Sullivan BM \& Donald AD (1973) Responses to infection with Haemonchus contortus and Trichostrongylus colibriformis in ewes of different reproductive status. International Journal for Parasitology 3, 521-530.

Papadopoulos E, Sotiraki S, Stamataris C, Lainas T, Himonas C, Katsaounis N \& Zygoyiannis D (2000) Effect of undergradable protein on nematode parasites in growing kids and lambs. Proceedings of the 8th Hellenic Veterinary Congress, p. 191. Athens: Greek Veterinary Medical Society.

Parkins JJ \& Holmes PH (1989) Effects of gastrointestinal helminth parasites on ruminant nutrition. Nutrition Research Reviews $\mathbf{2}$, 227-246.

Pine AP, Jessop NS, Allan GF \& Oldham JD (1994a) Maternal protein reserves and their influence on lactational performance in rats. 4. Tissue protein synthesis and turnover associated with mobilization of maternal protein. British Journal of Nutrition 72, 831-844.

Pine AP, Jessop NS \& Oldham JD (1994b) Maternal protein reserves and their influence on lactational performance in the rat. British Journal of Nutrition 71, 13-27.

Poelvoorde J (1973) Epidemiology of an Oesophagostomum spp. infection in boars. Vlaams Diergeneeskundig Tijdschrift 42, $120-124$.

Powanda MC (1977) Changes in body balances of nitrogen and other key nutrients: description and underlying mechanisms. American Journal of Clinical Nutrition 30, 1254-1268.

Rauw WM, Kanis E, Noordhuizen-Stassen EN \& Grommers FJ (1998) Undesirable side effects of selection for high production efficiency in farm animals: a review. Livestock Production Science 56, 15-33.

Reeds PJ, Fjeld CR \& Jahoor F (1994) Do the differences between the amino acid compositions of acute-phase and muscle proteins have a bearing on nitrogen loss in traumatic states? Journal of Nutrition 124, 906-910.

Richner H, Christe P \& Oppliger A (1995) Paternal investment affects prevalence of malaria. Proceedings of the National Academy of Sciences USA 92, 1192-1194.

Romjali E, Dorny P, Batubara A, Pandey VS \& Gatenby RM (1997) Peri-parturient rise in faecal strongyle egg counts of different genotypes of sheep in North Sumatra, Indonesia. Veterinary Parasitology 68, 191-196.

Rothwell TLW (1989) Immune expulsion of parasitic nematodes from the alimentary tract. International Journal for Parasitology 19, 139-168.

Rowe JB, Nolan JV, Chaneet GD, Teleni E \& Holmes PH (1988) The effect of haemonchosis and blood loss into the abomasum on digestion in sheep. British Journal of Nutrition 59, 125-139.

Sakanashi TM, Brigham HE \& Rasmussen KM (1987) Effect of dietary restriction during lactation on cardiac output, organ blood flow and organ weights of rats. Journal of Nutrition 117, 1469-1474.

Selby GR \& Wakelin D (1975) Suppression of the immune response to Trichuris muris in lactating mice. Parasitology 71, $77-85$.

Smith W, Jackson F, Jackson E \& Williams J (1983) Local immunity and Ostertagia circumcincta: changes in the gastric lymph of immune sheep after a challenge infection. Journal of Comparative Pathology 93, 479-488.

Smith W, Jackson F, Jackson E, Williams J \& Miller H (1984) Manifestations of resistance to ovine ostertagiasis associated with immunological responses in the gastric lymph. Journal of Comparative Pathology 94, 591-601.

Smith WD, Jackson F, Jackson E, Dawson AM \& Burrells C (1981) Changes in the flow and composition of gastric lymph in sheep repeatedly infected with Ostertagia circumcincta. Journal of Comparative Pathology 91, 553-564.

Sykes AR (2000) Environmental effects on animal production: the nutritional demands of nematode parasite exposure in sheep. Asian Australasian Journal of Animal Sciences 13, 343-350.

Takahashi K, Ohta N \& Akiba Y (1997) Influences of dietary methionine and cysteine on metabolic responses to immunological stress by Escherichia coli lipopolysaccharide injection, and mitogenic response in broiler chickens. British Journal of Nutrition 78, 815-821.

Taylor EL (1935) Seasonal fluctuation in the number of eggs of trichostrongylid worms in the faeces of ewes. Journal of Parasitology 21, 175-179.

Taylor LM, Parkins JJ, Arour J, Holmes PH, Bairden K, IbarraSilva AM, Salman SK \& McWilliam PN (1989) Pathophysiological and parasitological studies on Ostertagia ostertagi infections in calves. Research in Veterinary Science 46, $218-225$.

Thomas RJ \& Ali DA (1983) The effect of Haemonchus contortus infection on the pregnant and lactating ewe. International Journal for Parasitology 13, 393-398.

Trayhurn P (1985) Brown adipose tissue thermogenesis and the energetics of lactation in rodents. International Journal of Obesity 9, 81-88.

Trigg TE \& Topps JH (1981) Composition of body weight change during lactation in Hereford and Friesian cows. Journal of Agricultural Science, Cambridge 97, 147-157.

van Houtert MFJ, Barger IA, Steel JW, Windon RG \& Emery DL (1995) Effects of dietary protein intake on responses of young sheep to infection with Trichostrongylus colubriformis. Veterinary Parasitology 56, 163-180. 
van Houtert MFJ \& Sykes AR (1996) Implications of nutrition for the ability of ruminants to withstand gastrointestinal nematode infections. International Journal for Parasitology 26, $1151-1168$

van Zon AAJC \& Eling WMC (1980) Depressed malarial immunity in pregnant mice. Infection and Immunity 28, 630-632.

Waller PJ (1993) Control strategies to prevent resistance. Veterinary Parasitology 46, 133-142.

Wiehn J \& Korpimaki E (1998) Resource levels, reproduction and resistance to haematozoan infections. Proceedings of the Royal Society of London 265, 1197-1201.

Wiehn J, Korpimaki E \& Pen I (1999) Haematozoan infections in the Eurasian kestrel: effects of fluctuating food supply and experimental manipulation of parental effort. Oikos 84, 87-98.
Xiao L \& Herd RP (1994) Epidemiology of equine Cryptosporidium and Giardia infections. Equine Veterinary Journal 26, 14-17.

Yakoob A, Holmes PH \& Armour J (1983) Pathophysiology of gastrointestinal trichostrongyles in sheep: plasma losses and changes in plasma pepsinogen levels associated with parasite challenge of immune animals. Research in Veterinary Science 34, 305-309.

Yu A, Bruce LA, Calder AG, Milne E, Coop RL, Jackson F, Horgan GW \& MacRae JC (2000) Subclinical infection with the nematode Trichostrongylus colubriformis increases gastrointestinal tract leucine metabolism and reduces availability of leucine for other tissues. Journal of Animal Science 78, 380-390. 